\title{
Design, Modeling and Energy Management of a PEM Fuel Cell / Supercapacitor Hybrid Vehicle
}

\author{
Wahib Andari, Samir Ghozzi, Hatem Allagui and Abdelkader Mami \\ Analysis, Conception and Control Systems Laboratory-ENIT/FST \\ Campus Universitaire 2092 El Manar I. \\ Tunis, Tunisia
}

\begin{abstract}
This work concerns the study and the modeling of hybrid Proton Exchange Membrane (PEM) Fuel Cell electric vehicle. In fact, the paper deals with the model description of the powertrain which includes two energy sources: a PEM Fuel Cell as a primary source and a supercapacitor as a secondary source. The architecture is two degrees of freedom permitting a stability of the DC bus voltage. The hybridation of primary source with an energy storage system can improve vehicle dynamic response during transients and hydrogen consumption. The proposed energy management algorithm allows us to have a minimum hydrogen consumption. This algorithm is based on supercapacitor state of charge (SOC) control and acceleration/deceleration phases making possible braking energy recovery. The proposed model is simulated and tested using Matlab/Simulink software allowing rapid transitions between sources. The obtained results with the New European Driving Cycle (NEDC) cycle demonstrate a $22 \%$ gain in hydrogen consumption.
\end{abstract}

Keywords-PEM Fuel Cell; Powertrain; Electric vehicle; Supercapacitor; Energy management; Power system; hydrogen gain

\section{INTRODUCTION}

Fuel cell hybrid electric vehicles are currently considered as solution to reduce the pollution in the sector of urban transportation. The fuel cells represent one of the most promising renewable energy clean sources because of its zero emissions gas [1]. Proton Exchange Membrane (PEM) Fuel Cell is the primary preference in transportation sector due to the high power density, lower operating temperatures, good stability when submitted to mechanical vibration [2] and a low power on time compared to other types [3].

Integration of a bidirectional secondary source with PEM Fuel Cell like supercapacitors or battery allows reduction of fuel cell nominal power, minimizes hydrogen consumption and braking energy recovery [4].Many works are presented in literature where different topologies and strategies are discussed. In the work of Erdinc.O et al. [5],the supercapacitor SOC and vehicle speed are used to perform power management between the two sources. N. Mebarki et al. [6] proposed battery as a secondary source because of its higher specific energy. In this case, battery low power density may present some limitations in acceleration /deceleration phases. H.Aouzellag et al. [7] proposed to combine ultracapacitor with battery to overcome power delivery limitations of the PEM Fuel Cell. Different power management algorithms are presented in literature with the main objective to reduce hydrogen consumption and autonomy improving [8] among these algorithms we find dynamic programming, optimal control and intelligent techniques. This paper deals with the use of a supercapacitor as secondary source because of its high specific power and unlimited number of charge/discharge cycles compared to the battery [9]. The power train is modeled as presented in fig.1. It's composed mainly of a PEM Fuel Cell, supercapacitor, boost, buck-boost converter and permanent magnet synchronous motor (PMSM) connected to the inverter. The whole model of the power train is validated with Matlab Simulink software.

In this paper we present a simple energy management algorithm compared with other methods. This strategy allows simple implementation and good results especially with urban cycles. This paper is structured as follows: an introduction is presented in Section I. In section II, we presented the power sources modeling. In Sections III-IV, we presented the power train and motor description models. The proposed energy management strategy is presented in Section V. Simulation results and conclusion are presented and discussed in sections VI-VII. 


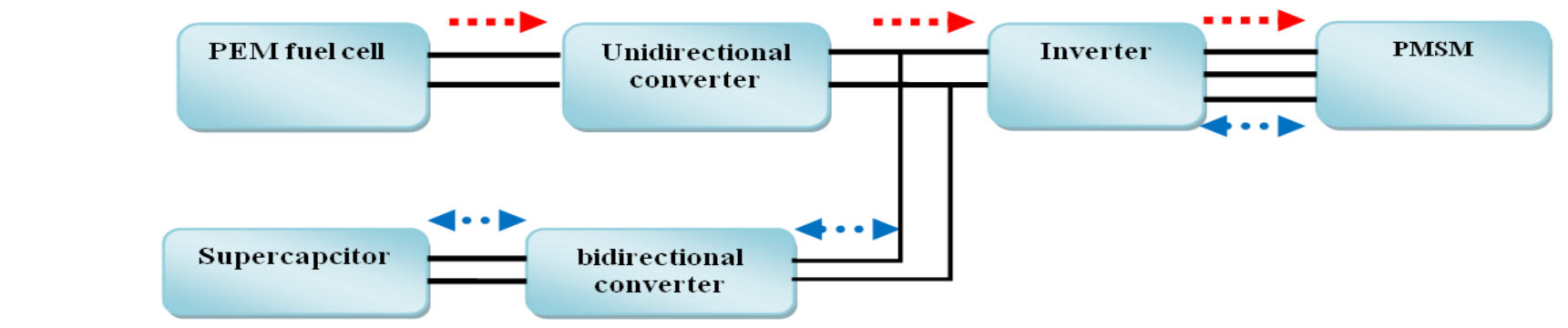

$\cdots$ Unidirectional energy flow directions
$\cdots$

Fig. 1. Power system of fuel cell/SC hybrid vehicle

\section{ENERGY SOURCES}

\section{A. PEM Fuel Cell modeling}

One of the objectives in this paper is to study the mathematical model of the PEM Fuel Cell. Several works $[10,11]$ proposed a dynamic models that describe the polarization curve of the PEM Fuell Cell. When a current flows in the external circuit, the potential of the cell is lower than the theoretical potential. This is due to different voltage drops: the activation, the ohmic and the concentration losses.

The Fuel Cell chosen in this work is the Mark 902PEM Fuel Cell from Ballard [12] with $85 \mathrm{~kW}$ nominal power at $280 \mathrm{~V}$. The parameters of the fuel cell are given in table 2. A boost converter is used to interface the PEM Fuel Cell to the DC bus voltage [13].

The PEMFC output voltage can be written as follows:

$$
\mathrm{V}=\mathrm{E}_{\text {nerst }}-\mathrm{V}_{\text {act }}-\mathrm{V}_{\text {ohm }}-\mathrm{V}_{\text {conc }}
$$

Where:

$$
E_{\text {nerst }}=E^{0}-R T \ln \frac{\mathrm{PH}_{2} \sqrt{\mathrm{Po}_{2}}}{\mathrm{PH}_{2} \mathrm{O}}
$$

Where $\mathrm{V}, \mathrm{E}_{\text {nerst }}, \mathrm{V}_{\text {act }}, \mathrm{V}_{\text {ohm }}, \mathrm{V}_{\text {conc }}, \mathrm{P}_{\mathrm{H} 2}, \mathrm{P}_{\mathrm{O} 2}, \mathrm{P}_{\mathrm{H} 2 \mathrm{O}}$ are respectively: the fuel cell voltage $(\mathrm{V})$, the activation Voltage losses, the ohmic Voltage losses (V), the concentration Voltage losses (V), the voltage Nernst (V) and the partial pressure of hydrogen, oxygen and water (atm).

The activation losses can be expressed by the Tafel equation:

$$
\mathrm{V}_{\mathrm{act}}=\frac{\mathrm{RT}}{2 \alpha \mathrm{F}} \ln \left(\frac{\mathrm{I}_{\mathrm{FC}}}{\mathrm{I}_{0}}\right)
$$

The ohmic losses are given by the following equation:

$$
\mathrm{V}_{\text {ohmic }}=\mathrm{I}_{\mathrm{FC}} \mathrm{R}
$$

The concentration losses can be expressed as:

$$
\mathrm{V}_{\text {conc }}=-\frac{\mathrm{RT}}{2 \mathrm{~F}} \ln \left(1-\frac{\mathrm{j}}{\mathrm{j}_{\max }}\right)
$$

Where $I_{F C}, \alpha, I_{0}$ and $j_{\max }$ are respectively: the current of PEMFC(A), the tafel slope for the activation losses, the exchange current density for the activation $\left(\mathrm{mA} / \mathrm{cm}^{2}\right)$ and the maximal current density for the concentration $\left(\mathrm{A} / \mathrm{cm}^{2}\right)$. follows:

The quantity of hydrogen consumed is expressed as

$$
H_{2 \text { conso }}=\frac{\mathrm{N}_{\text {cell }} \mathrm{I}_{\mathrm{FC}}}{2 \mathrm{~F}}
$$

Where $\mathrm{H}_{2 \text { conso }}, \mathrm{N}_{\text {cell }}$ are respectively: the $\mathrm{H}_{2}$ consumption amount $(\mathrm{mol} / \mathrm{s})$ and the number Cell of PEM Fuel Cell.

TABLE I. PARAMETRS OF THE PEM Fuel CELL

\begin{tabular}{|l|l|l|l|}
\hline Parameters & Symbol & Values & Units \\
\hline $\begin{array}{l}\text { The constant of } \\
\text { faraday }\end{array}$ & $\mathrm{F}$ & 96439 & $\mathrm{C} / \mathrm{mol}$ \\
\hline Universal gas constant & $\mathrm{R}$ & 8.314 & $\mathrm{~J} / \mathrm{mol}$ \\
\hline $\begin{array}{l}\text { Resistance of the } \\
\text { electrolyte }\end{array}$ & $R_{M}$ & 0.00003 & $\mathrm{Ohm}$ \\
\hline Temperature & $\mathrm{T}$ & $80^{\circ} \mathrm{C}$ & Celsius \\
\hline Nominal Current & $\mathrm{I}_{\text {nominal }}$ & 300 & $\mathrm{~A}$ \\
\hline Voltage & $\mathrm{V}_{\text {fuel }}$ & 280 & $\mathrm{~V}$ \\
\hline Power & $\mathrm{P}_{\text {fuel }}$ & 85 & $\mathrm{KW}$ \\
\hline
\end{tabular}

The simulation current-voltage characteristic of a MK 902 PEM Fuel Cell model is shown in Fig. 2

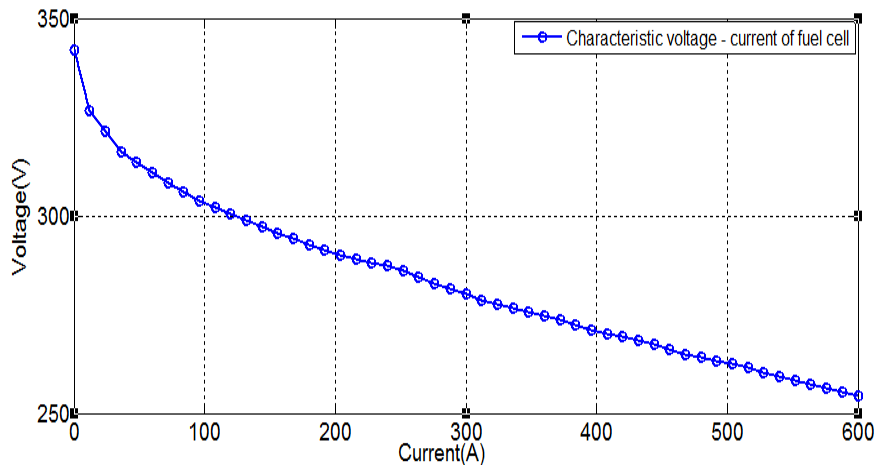

Fig. 2. PEM fuel cell voltage-current characteristic

\section{B. Supercapacitor}

This second energy source is chosen to respond to power requirements of hybrid vehicle. A 63F Maxwell BMOD0063P125B08 module [14] is used in this work. The parameters of the supercapacitor model are given in table 2. A buck/boost converter is used to interface the supercapacitor to DC voltage bus [15]. 
This converter allows the power flow between the energy storage system and the PMS motor. In the Buck mode operation, the secondary source receives the energy during braking phases (charge phase of the supercapacitor). In the boost mode operation, the supercapacitor generates the power and assists the fuel cell (discharge phase of the supercapacitor).

The open circuit voltage of a supercapacitor is given by the following expression:

$$
\mathrm{E}_{\mathrm{sc}}=\mathrm{E}_{\mathrm{sc} 0}-\frac{1}{\mathrm{C}_{\mathrm{sc}}} \int_{0}^{\mathrm{t}} \mathrm{i}_{\mathrm{sc}} \mathrm{dt}
$$

Where $\mathrm{C}_{\mathrm{sc}}$ and $\mathrm{I}_{\mathrm{SC}}$ are respectively: the capacity of the supercapacitor (F) and the supercapacitor current (A).

The energy of a supercapacitor is:

$$
\begin{aligned}
& X_{\mathrm{sc}}=\frac{\mathrm{C}_{\mathrm{sc}} \mathrm{E}_{\mathrm{sc}}^{2}}{2} \\
& \mathrm{X}_{\mathrm{sc}-\max }=\frac{\mathrm{C}_{\mathrm{sc}} \mathrm{E}_{\mathrm{sc} 0}^{2}}{2}
\end{aligned}
$$

The state of charge (SOC) can be written as:

$$
\mathrm{SOC}=\frac{\mathrm{x}_{\mathrm{sc}}}{\mathrm{x}_{\mathrm{sc}-\mathrm{max}}}
$$

The output voltage of a supercapacitor is:

$$
\mathrm{V}_{\mathrm{sc}}=\mathrm{E}_{\mathrm{sc}}-\mathrm{R}_{\mathrm{sc}} \mathrm{i}_{\mathrm{sc}}
$$

Where $\mathrm{X}_{\mathrm{SC}}, \mathrm{X}_{\mathrm{SC}-\max }$, and $\mathrm{R}_{\mathrm{sc}}$ are respectively :the internal resistance of a supercapacitor $(\Omega)$, the energy contained in a supercapacitor $(\mathrm{J})$ and the maximum energy contained in a supercapacitor $(\mathrm{J})$.

TABLE II. PARAMETERS OF THE SUPERCAPACITOR

\begin{tabular}{|l|l|l|}
\hline Parameters & Values & Units \\
\hline Rated Capacitance & 63 & $\mathrm{~F}$ \\
\hline Maximum ESR & 18 & $\mathrm{~m} \Omega$ \\
\hline Rated Voltage & 125 & $\mathrm{~V}$ \\
\hline Absolute maximum current & 1900 & $\mathrm{~A}$ \\
\hline Leakage current at $25^{\circ} \mathrm{C}$ & 10 & $\mathrm{~mA}$ \\
\hline Capacitance of individual cells & 3000 & $\mathrm{~F}$ \\
\hline Mass, typical & 61 & $\mathrm{Kg}$ \\
\hline Usable specific power & 1700 & $\mathrm{~W} / \mathrm{kg}$ \\
\hline Specific energy & 23 & $\mathrm{Wh} / \mathrm{kg}$ \\
\hline
\end{tabular}

\section{POWERTRAIN DESCRIPTION MODEL}

The powertrain model is composed of four sub-models: the electrical machine, the reducer / transmission, wheels and the vehicle [16].

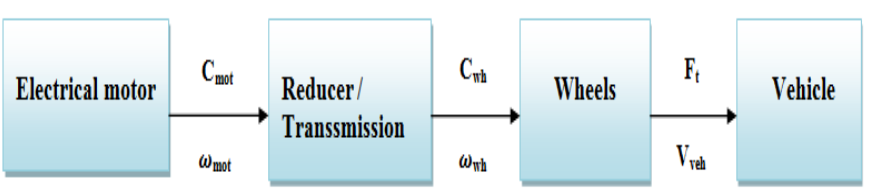

Fig. 3. Scheme of the powertrain

The traction force is given by the following equation:

$$
\mathrm{F}_{\text {traction }}=\mathrm{F}_{\text {mot }}-\mathrm{F}_{\text {roll }}
$$

Where the acceleration force and the friction force to the advancement are respectively given as follows:

$$
\begin{aligned}
& \mathrm{F}_{\text {mot }}=\frac{\mathrm{C}_{\text {wheel }}}{\mathrm{R}_{\text {wheel }}} \\
& \mathrm{F}_{\text {roll }}=\mathrm{M}_{\text {veh }} \mathrm{C}_{\mathrm{r}} \cos (\alpha)
\end{aligned}
$$

The coefficient of friction $C_{r}$ is given as follow:

$$
\mathrm{C}_{\mathrm{r}}\left(\mathrm{V}_{\mathrm{veh}}\right)=\mathrm{C}_{\mathrm{r}}^{0}+\mathrm{K}_{\mathrm{c}} \mathrm{V}_{\text {veh }}^{2}
$$

The aerodynamic force $\mathrm{F}_{\text {aero }}$ is given by :

$$
\mathrm{F}_{\text {aero }}=\frac{1}{2} \rho_{\text {air }} \mathrm{A}_{\mathrm{f}} \mathrm{C}_{\mathrm{x}} \mathrm{V}_{\text {veh }}^{2}
$$

The resistance of mounted side $\mathrm{F}_{\text {slope }}$ is :

$$
F_{\text {slope }}=M_{\text {veh }} g \sin (\alpha)
$$

The fundamental principle of the vehicle dynamics is given by the following equation:

$$
\frac{\mathrm{dv}(\mathrm{t})}{\mathrm{dt}}=\mathrm{F}_{\text {traction }}-\mathrm{F}_{\text {aeoro }}-\mathrm{F}_{\text {slope }}
$$

The torque and speed motor are given by equations (19) (20):

$$
\begin{aligned}
& \mathrm{C}_{\text {mot }}=\frac{\mathrm{C}_{\text {wheels }}}{\mathrm{r}_{\text {red }}} \\
& \omega_{\text {mot }}=\omega_{\text {wheels }}
\end{aligned}
$$

The final expression of load torque is given by the following expression:

$$
\mathrm{C}_{\mathrm{r}}=\frac{\mathrm{R}_{\text {whel }}}{\mathrm{r}_{\text {red }}}\left(\mathrm{F}_{\text {roll }}+\mathrm{F}_{\text {aeor }}+\mathrm{F}_{\text {slope }}\right)
$$

The different extracted parameters are defined as:

$\alpha$ :Road slope angle (rd)

$\mathrm{R}_{\text {wheel }}$ : Wheel radius (m)

\begin{tabular}{|c|c|c|c|}
\hline Parameters & Symbol & Values & Units \\
\hline Vehicle total mass & $\mathrm{Mv}$ & 1300 & $\mathrm{~kg}$ \\
\hline Rolling resistance force constant & $\mathrm{Fr}$ & 0.01 & $\mathrm{~s}^{2} / \mathrm{m}^{2}$ \\
\hline Air density & $\rho$ & 1.20 & kg.m $\mathrm{m}^{3}$ \\
\hline Aerodynamic drag coefficient & $\mathrm{C}_{\mathrm{x}}$ & 0.30 & - \\
\hline Acceleration due to gravity & $\mathrm{G}$ & 9.8 & $\mathrm{~m} \cdot \mathrm{s}^{2}$ \\
\hline
\end{tabular}

$\rho_{\text {air }}:$ Air density $\left(\mathrm{kg} / \mathrm{m}^{3}\right)$

$\mathrm{C}_{\mathrm{x}}$ : Aerodynamic drag coefficient

$\mathrm{F}_{\text {tire }}:$ Rolling resistance force $(\mathrm{N})$

$\mathrm{F}_{\text {roll }}:$ Friction force to the advancement $(\mathrm{N})$

$\mathrm{M}_{\text {veh }}$ : Vehicle weight $(\mathrm{kg})$

$\mathrm{V}_{\text {veh }}$ : Vehicle speed $(\mathrm{m} / \mathrm{s})$

$\mathrm{F}_{\text {aero }}$ : Effort of aerodynamic resistance $(\mathrm{N})$

$\mathrm{A}_{\mathrm{f}}$ : Front area of the vehicle $\left(\mathrm{m}^{2}\right)$

$\mathrm{F}_{\text {slope }}$ : Resistance of mounted side $(\mathrm{N})$

$\mathrm{g}$ : Gravitational acceleration $(\mathrm{m} / \mathrm{s})^{2}$

$\mathrm{F}_{\text {traction }}:$ Traction force $(\mathrm{N})$

The parameters of the Hybrid fuel cell Vehicle model are given in Table.III

TABLE III. PARAMETERS OF HEV VEHICLE MODEL

The Simulink model of the vehicle power train given in fig.4 is used to validate our control method.

\section{PMSM MODEL}

The model the PMSM in $\mathrm{d}-\mathrm{q}$ frame can be expressed by the following equations [17] 


$$
\left\{\begin{array}{c}
\mathrm{V}_{\mathrm{q}}=\mathrm{R}_{\mathrm{s}} \mathrm{I}_{\mathrm{q}}+\mathrm{L}_{\mathrm{q}} \mathrm{pi}_{\mathrm{q}}+\omega_{\mathrm{r}} \mathrm{L}_{\mathrm{d}} \mathrm{i}_{\mathrm{d}}+\omega_{\mathrm{r}} \Phi_{\mathrm{f}} \\
\mathrm{V}_{\mathrm{d}}=\mathrm{R}_{\mathrm{s}} \mathrm{I}_{\mathrm{d}}+\mathrm{L}_{\mathrm{d}} \mathrm{pi}_{\mathrm{d}}-\omega_{\mathrm{r}} \mathrm{L}_{\mathrm{d}} \mathrm{i}_{\mathrm{q}} \\
\Phi_{\mathrm{d}}=\mathrm{L}_{\mathrm{d}} \mathrm{i}_{\mathrm{d}}+\varphi_{\mathrm{f}} \\
\Phi_{\mathrm{q}}=\mathrm{L}_{\mathrm{q}} \mathrm{i}_{\mathrm{q}} \\
\mathrm{T}_{\mathrm{em}}=\frac{3}{2} \mathrm{p}\left(\Phi_{\mathrm{f}} i_{q}+\left(L_{d}-L_{q}\right) i_{q} i_{d}\right.
\end{array}\right.
$$

where the rotor speed is derived from the following equation:

$$
\mathrm{T}_{\mathrm{em}}=\mathrm{T}_{\mathrm{L}}+\mathrm{B} \omega_{\mathrm{m}}+\mathrm{J} \frac{\mathrm{d} \Omega}{\mathrm{dt}}
$$

A Space Vector Pulse With Modulation (SVPWM) technique is applied to inverter in order to minimize converter losses. This technique is a better control method of output voltage under DC voltage variation then classical PWM [18].

The different extracted parameters are defined as:

$\mathrm{V}_{\mathrm{d}}, \mathrm{V}_{\mathrm{q}}: \mathrm{d}, \mathrm{q}$ voltage $(\mathrm{V})$

$\mathrm{i}_{\mathrm{d}}, \mathrm{i}_{\mathrm{q}}:$ Stator currents $(\mathrm{A})$

$\mathrm{L}_{\mathrm{d}}$, and $\mathrm{L}_{\mathrm{q}}$ : Inductances $(\mathrm{H})$

$\Phi_{\mathrm{d}}$ and $\Phi_{\mathrm{q}}:$ Stator flux linkages (Weber)

$\mathrm{R}_{\mathrm{s}}$ :Stator winding resistance $(\Omega)$

$\omega_{\mathrm{r}}:$ Rotor speed $(\mathrm{rd} / \mathrm{s})$

$\mathrm{T}_{\mathrm{L}}$ : Load torque $(\mathrm{Nm})$

$\Omega$ : Mechanical pulse of the rotor $(\mathrm{rd} / \mathrm{s})$

$\mathrm{J}$ : Total inertia brought back to the rotor $\left(\mathrm{kg} \cdot \mathrm{m}^{2}\right)$

\section{ENERGY MANAGEMENT}

The energy management in hybrid fuel cell vehicle is the most important factor that can improve fuel cell lifetime, cost and hydrogen consumption [19]. The energy management must power flow between the storage system (UC) and the power train with the goal to minimize FC current and to capture the braking energy during the various driving phases especially in urban cycles. There are three principal methods of energy optimization in literature:

- Dynamic programming methods with different initial and final conditions. These methods are used with predefined cycles and are not optimal for athor trajectories [20].

- Optimal control methods based on a minimization of analytical expression of energy under constraints [21]. This is a hard task and requires a long time of calculus when implemented. The accuracy of optimal point strongly depends of the used model [22].

- Intelligent techniques like fuzzy logic [23]or neural network are proposed to overcome the problems of previous two methods [24]. These methods are heavy to implement and need a powerful DSP and may present some oscillations [25].

In this paper, we present a simplified algorithm based on the state of charge of the supercapacitor and the driving phase.

The energy management algorithm proposed chosen is to minimize the fuel cell power, which corresponds to the minimization of the hydrogen consumption. The Supercapacitor provides the difference between the power delivered from the fuel cell and the demanded power from the PMS Motor. The relationship of power between the fuel cell, the supercapacitor and the load is given as follows:

$$
P_{\text {Load }}=P_{\text {fuel }}+P_{S C}
$$

This energy management algorithm is given in fig. 4 and includes 3 operating modes:

Mode 1: This mode is characterized by the activation of Storage system .The supercapacitor recovers the energy braking (deceleration phase).

Mode 2: This mode is characterized by the activation of fuel cell . At this moment, the PEM fuel cell supplies the PMS motor (steady speed )

Mode 3: The load composed of the PMS motor receives the power from the storage system (Acceleration phase).

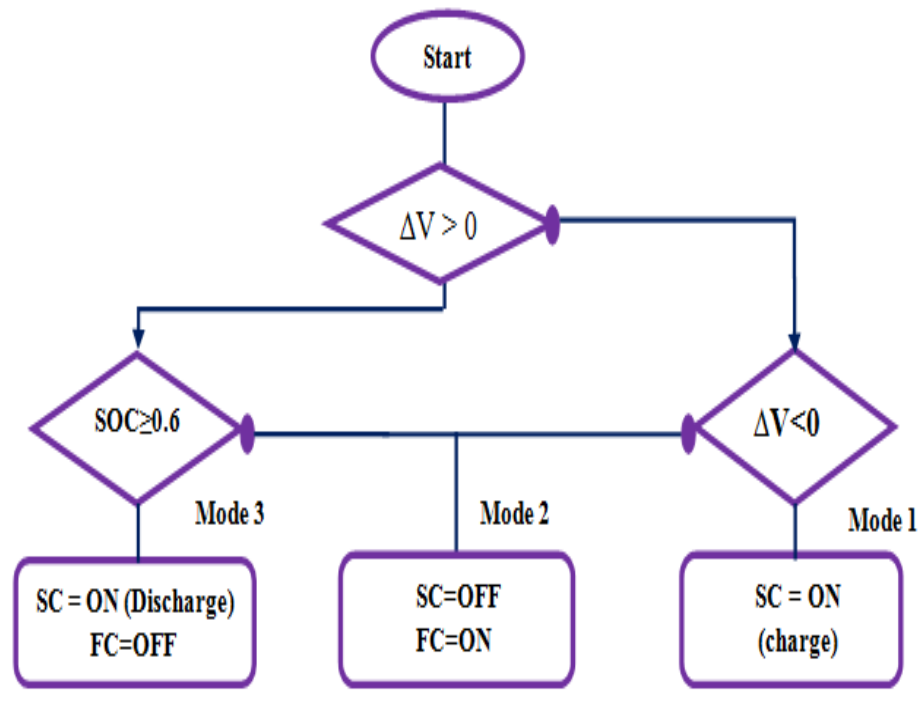

Fig. 4. Energy management algorithm

\section{Simulation Results AND Discussion}

The Fuel cell hybrid electric vehicle model was tested in Matlab/Simulink software with urban NEDC (New European Driving Cycle) driving cycle using the parameters given in tables 1,2 and 3.

The NEDC cycle is given in fig.5. It's applied to the vehicle during $1200 \mathrm{~s}$ and is characterized by a maximum speed of $120 \mathrm{~km} / \mathrm{h}$, maximum acceleration of $1.042 \mathrm{~m} / \mathrm{s}^{2}$ and average speed of $33.35 \mathrm{~km} / \mathrm{h}$. 


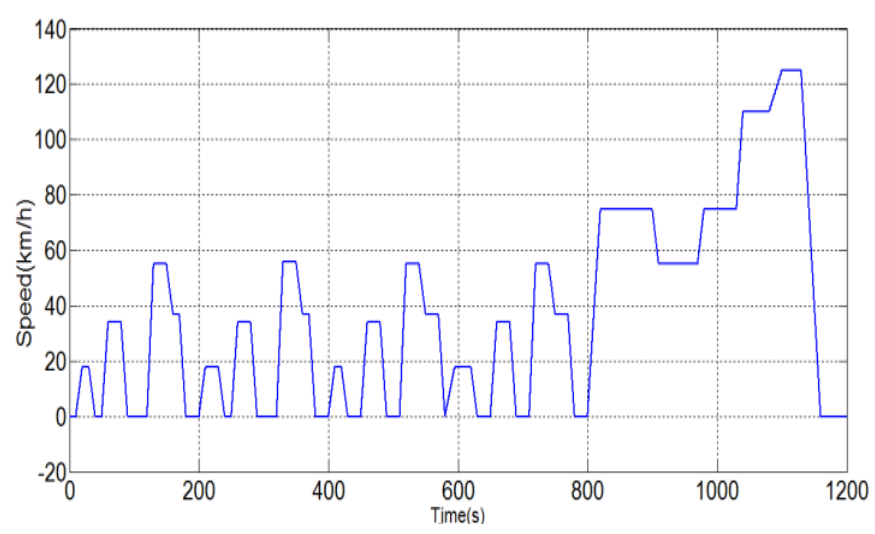

Fig. 5. The NEDC profile

The hydrogen consumed by the fuel cell alone without energy management algorithm is $250 \mathrm{~g}$ during this driving cycle is given in fig 6 . The hydrogen consumed when the proposed energy management algorithm is implemented is $180 \mathrm{~g}$ during this driving cycle is given in fig 7.The efficiency of the proposed energy management algorithm in urban cycles is validated by fig.8. By using the proposed energy management the consumption of hydrogen is improved by seventy grams.

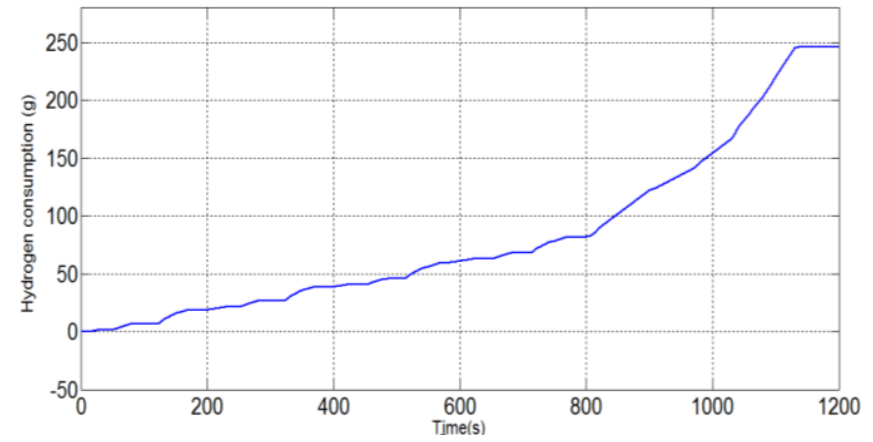

Fig. 6. Hydrogen consumption without supercapacitor

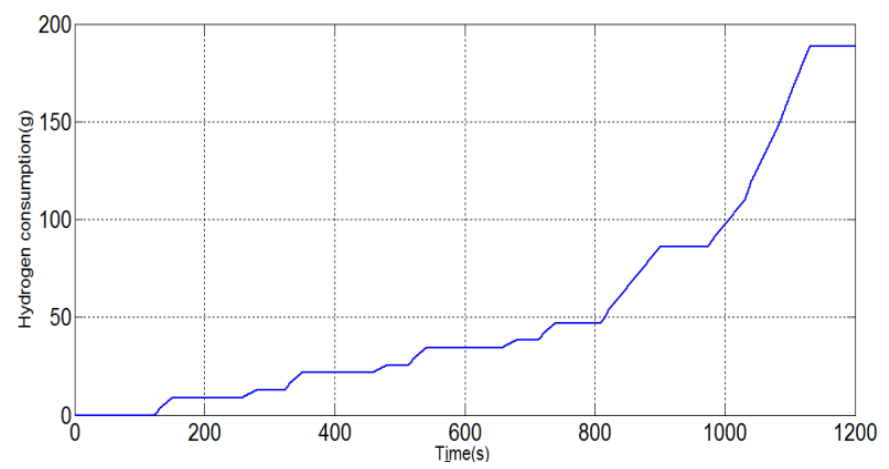

Fig. 7. Hydrogen consumption with our energy management algorithm

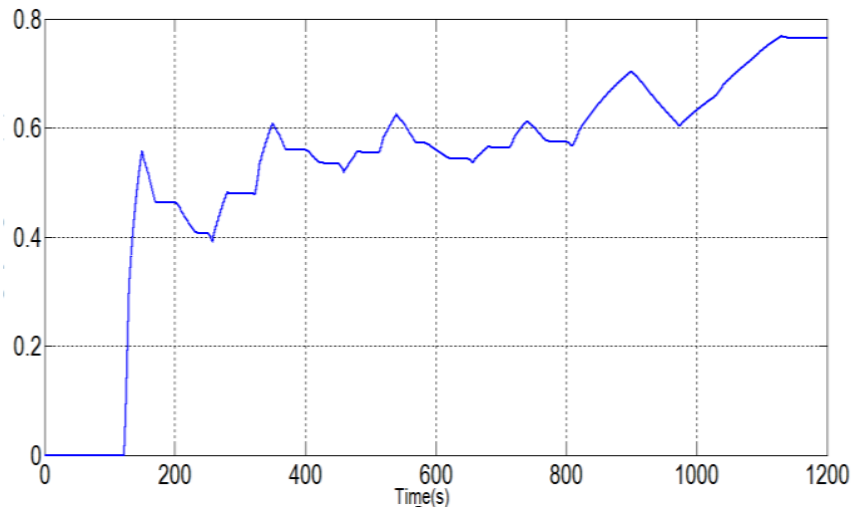

Fig. 8. Gain in hydrogen consumption in pu

Table IV shows the gain consumption of hydrogen of each algorithm for "optimal control, fuzzy logic, proposed energy management algorithm ". We can show that the proposed method attains the biggest values gain in consumption hydrogen compared to other mentioned methods.

TABLE IV. COMPARISON OF DIFFERENT METHOD FOR THE DIFFERENT POWER MANAGEMENT ALGORITHM

\begin{tabular}{|l|l|}
\hline Method & Gain hydrogen consumption \\
\hline Optimal control [22] & $18 \%$ \\
\hline Fuzzy logic [26] & $18.7 \%$ \\
\hline Proposed algorithm & $22 \%$ \\
\hline
\end{tabular}

The proposed energy management algorithm was tested with a minimal SOC value of 0.6. The simulation results given in fig. 9 show a good control of the state of charge of the supercapacitor while optimizing hydrogen consumption of the fuel cell hybrid electric vehicle. The hole braking energy is recovered without exceeding allowed SOC values which means a good choice of supercapacitor value.

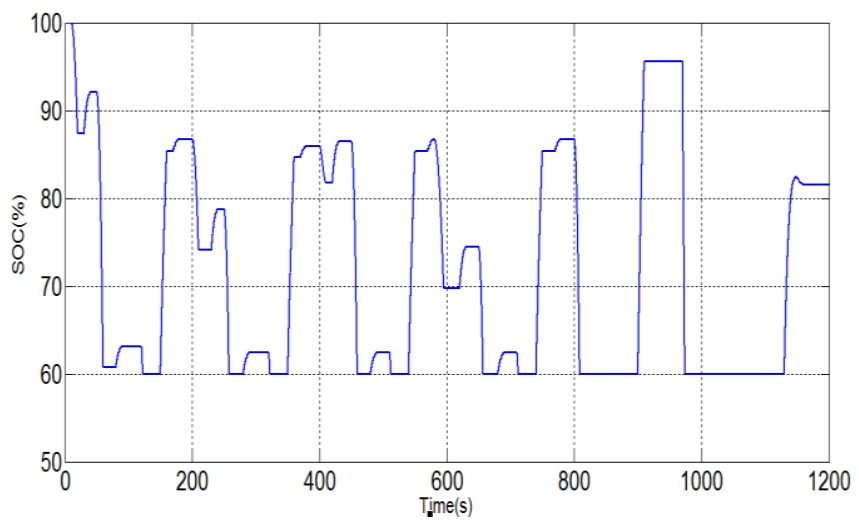

Fig. 9. The state of charge of the supercapacitor 


\section{CONCLUSION}

In this paper, we proposed a fuel cell hybrid electric vehicle model which includes a PEM fuel cell, a supercapacitor and PMS motor. The power system includes a buck boost static converter with the secondary source allowing bidirectional energy flow.

We developed a simplified energy management algorithm based on SOC of the supercapacitor and the sign of the acceleration. NEDC urban cycle simulation results obtained by implementation of the hole system in MATLAB-Simulink software shows a $22 \%$ gain of hydrogen consumption. SOC simulation during this cycle proves recovery of the hole braking energy. A perspective of this work is the implementation of this optimization algorithm on an embedded electronic board in order to validate the simulation obtained results using Matlab / Simulink.

\section{REFERENCES}

[1] M. W. Ellis, M. R. V. Spakovsky, and D. J. Nelson, “ Fuel cell systems: efficient, flexible energy conversion,"Proc. IEEE, vol.89,2001,pp. 1808-1818.

[2] Ke Jin, Xinbo Ruan, and Mengxiong Yang, "Power Management for Fuel-Cell Power System Cold Start," IEEE Transactions On power Electronics, vol.24,2009,2391-2395

[3] M.uZunogli and M.S.Alam, "Dynamic Modeling Design and simulation of a PEM Fuel cell/Ultracapacitor Hybrid system for vehicular Applications ,'Energy conversion \&Management,vol.48, 2007,pp. 15441553.

[4] Phatiphat Thounthong, Pietro Tricoli, Bernard Davat, "Performance investigation of linear and nonlinear controls for a fuel cell/supercapacitor hybrid power plan ,"J. Electrical Power and Energy Systems,vol.54, 2014,pp.454-464.

[5] Erdinc O, Vural B, Uzunoglu M, Ates Y, "Modeling and analysis of an FC/UC hybrid vehicular power system using a wavelet fuzzy logic based load sharing and control algorithm,'Int J Hydrogen energy ,vol.34, 2009,pp.5223-5233

[6] N. Mebarki, T. Rekioua , Z. Mokrani ,"PEM fuel cell/ battery storage system supplying electric vehicle," Int J Hydrogen Energy ,vol.41,2016,pp.1-13.

[7] Haroune Aouzellag', Kaci Ghedamsi, Djamel Aouzellag "Energy management and fault tolerant control strategies for fuel cell/ultracapacitor hybrid electric vehicles to enhance autonomy, efficiency and life time of the fuel cell system," International Journal Hydrogen Energy, vol.40, 2015pp.7204-7213.

[8] João Bravo „João Ribau , carla silva,“ The influences of energy storage and energy management strategies on fuel consumption of a fuel cell hybrid vehicle,"IFAC Proceedings ,vol.45, 2012,pp.233-240.

[9] N. Benyahia', H. Denoun, M. Zaouia, "Power system simulation of fuel cell and supercapacitor based electric vehicle using an interleaving technique,"vol.40, 2015.pp.15806-15814.

[10] J. M. Corrêa, F. A. Farret, L. N. Canha and M. G. Simões , "Simulation of fuel-cell stacks using a computer-controlled power rectifier with the purposes of actual high-power injection applications,"IEEE Trans. on Industrial Applications, vol.39 , 2003,pp.1136 - 1142.

[11] F. Millo a , S. Caputo a , A. Piu, “ Analysis of a HT-PEMFC range extender for a light duty full electric vehicle (LD-FEV), ,'International Journal Hydrogen Energy ,vol.41,2016,pp.1-10.

[12] Ballard Mark 902Available at: http://www.ataca.tk/MAN5100067.pdf

[13] P. Garcia , J.P. Torreglosa, L.M. Fernandez, "Viability study of a FC-battery-SC tramway controlled by equivalent consumption minimization strategy," International Journal Hydrogen Energy , vol37, 2012pp. $9368-9382$.

[14] Maxwell Technologies. Maxwell technologiesBMODOO63e125VAvailable:http://about.maxwell.com/ult racapacitors/products/modules/bmod0063-125v.asp; 2011.

[15] Jenn-Jiang Hwang, Yu-Jie Chen, Jenn-Kun Kuo , "The study on the power management system in a fuel cell hybrid vehicle,'International Journal Hydrogen Energy ,vol.37,2014,pp.4476 - 4489.

[16] Mingyu Huang , Pengpeng Wen, Zheng Zhang, "Research on hybrid ratio of fuel cell hybrid vehicle based on ADVISOR,'International Journal Hydrogen Energy, vol.41,2016: pp.1 - 5.

[17] Haroune Aouzellag, Kaci Ghedamsi, Djamel Aouzellag, Energy management and fault tolerant control strategies for fuel cell/ultra-capacitor hybrid electric vehicles to enhance autonomy, efficiency and life time of the fuel cell system,'’International Journal Hydrogen Energyvol,vol.40, 2015,pp.7204-7213.

[18] N. Sulaiman , M.A.Hannan , A.Mohamed, "A review energy managments system for fuel cell hybrid electric vehicle," Issues and challenges Renewable and Sustainable Energy Reviews ,vol.52, 2015,pp.802-814 .

[19] C.H. Zheng, N.W. Kim, S.W. Cha, " Optimal control in the power management of fuel cell hybrid vehicles,'International Journal Hydrogen Energy ,2012,vol.37,pp.655-663.

[20] Dima Fares , Riad Chedid , Ferdinand Panik, "Dynamic programming technique for optimizing fuel cell hybrid vehicles,'International Journal Hydrogen Energy ,vol.40, 2015,pp.7777-7790.

[21] Xu LF, Li JQ, Hua JF, Li XJ, Ouyang MG, “ Optimal vehicle control strategy of a fuel cell/battery hybrid city bus," Int J Hydrogen Energy,vol34, 2009,pp.7323-7333.

[22] Wei-Song Lin', Chen-Hong Zheng, "Energy management of a fuel cell/ultracapacitor hybrid power system using an adaptive optimalcontrol method," Journal of Power Sources,vol.196, 2011,pp.3280-3289.

[23] Kisacikoglu MC, Uzunoglu M, Alam MS, "Load sharing using fuzzy logic control in a fuel cell/ultracapacitor hybrid vehicle ,'Int J Hydrogen Energy,vol.34, 2009,pp.1497-1507.

[24] Saman Ahmadi, S.M.T. Bathaee, "Multi Objective genetic optimization of the fuel cell hybrid vehicle supervisory system: Fuzzy logic andoperating mode control strategies," International Journal Hydrogen Energy,vol.40, 2015, pp.12512-12521.

[25] Hanane Hemi , Jamel Ghouili, Ahmed Cheriti , “A real time fuzzy logic power management strategy for a fuel cell vehicle ,"Energy Conversion and Management,vol.80, 2014 ,pp.63-70.

[26] M.N. Sid1, K. Nounou1, M. Becherif ,"Energy Management and Optimal Control Strategies of Fuel cell/Supercapacitors Hybrid Vehicle ,'IEEE. International Conference on Electrical Machines (ICEM), 2014, pp: $2293-2298$ 